\title{
A Case Non-Autochthonous Canine Visceral Leismaniosis in the Municipality of Guarulhos, São Paulo, Brazil
}

\author{
Un Caso de Leismaniosis Visceral Canina No Autóctona en el Municipio de Guarulhos, \\ São Paulo, Brasil
}

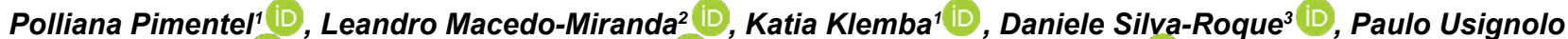 \\ Carnauba-Vicente $^{3}$ (D), João Carlos Lopes-Costa ${ }^{2}$ (D), Nathálya dos Santos-Martins ${ }^{4}$ (i) and Diego Carvalho-Viana ${ }^{2,5 *}$ \\ ${ }^{1}$ PUC. São Paulo, Brasil. ²Programa de Pós-Graduação em Ciência Animal, Universidade Estadual do Maranhão. São Luís, Maranhão, \\ Brasil. ${ }^{3}$ Universidade Guarulhos. São Paulo, Brasil. ${ }^{4}$ Universidade Federal do Maranhão (UFMA). São Luís, Maranhão, Brasil \\ ${ }^{5}$ Universidade Estadual da Região Tocantina do Maranhão (UEMASUL). Imperatriz, Maranhão, Brasil. \\ *Email:dieob@bol.com.br
}

\begin{abstract}
A male canine, two years old, with no known breed, with a history of diarrhea and ticks, was submitted to a private veterinary clinic in the City of Guarulhos, São Paulo State, Brazil: presenting weight loss, alopecia and intense pruritus. The owner reported that the dog was a native of the City of Votuporanga, São Paulo State. Blood samples were collected for blood counts and biochemical measurements, and rapid tests were performed with commercial kits for the detection of Ehrlichia canis, Anaplasma spp., Borrelia burgdorferi and Canine distemper. Due to the hematological and biochemical changes, the negative results, and the origin of the animal, it was decided to perform a rapid test for leishmaniasis, where this test presented a positive result, later confirmed by Polymerase Chain Reaction. The Leishmaniose continue advancing, being able to settle in non-endemic areas.
\end{abstract}

Key words: Canine; metropolis; Leishmania (L) infantum; Lutzomyia longipalpis

\section{RESUMEN}

Un canino macho, de dos años, mestizo, con antecedente de diarrea y garrapatas, con adelgazamiento, alopecia y prurito intenso, fue remitido a una clínica veterinaria privada de la ciudad de Guarulhos, estado de São Paulo, Brasil. El tutor informó que el perro era de la ciudad de Votuporanga, estado de São Paulo. Se recolectaron muestras de sangre para hemograma y mediciones bioquímicas, y se realizaron pruebas rápidas con kits comerciales para la detección de Ehrlichia canis, Anaplasma spp., Borrelia burgdorferi y moquillo canino. Ante los cambios hematológicos y bioquímicos, los resultados negativos y el origen del animal, se decidió realizar una prueba rápida para leishmaniasis, donde se obtuvo un resultado positivo, posteriormente confirmado por una prueba de Reacción en Cadena de la Polimerasa. La leishmaniosis continúa avanzando y puede establecerse en áreas no endémicas.

Palabras clave: Canino; metrópoli; Leishmania (L) infantum; Lutzomyia longipalpis 


\section{INTRODUCTION}

Leishmaniose is a chronic infectious, cosmopolitan and zoonotic disease caused by protozoa of the family Trypanosomatidae, genus Leishmania [9]. The species responsible for causing Canine Visceral Leishmaniasis (CVL) was Leishmania (L) infantum [6]. In Brazil, the main vector involved in transmission is the phlebotomine Lutzomyia longipalpis [1], with dogs (Canis lupus) being the main reservoirs in the urban environment, as they can present a large amount of amastigote forms in the skin, increasing the chances of infecting the vector [2].

CVL may present in symptomatic and asymptomatic forms, with the symptomatic form having several clinical signs, such as poor body condition, lymphadenomegaly, cutaneous alterations, onychogrifosis, purulent keratoconjunctivitis, epistaxis, mucous pallor, among others [3]. According to the Visceral Leishmaniasis Surveillance and Control Program in the State of São Paulo, the L. longipalpis vector was detected in 177 Municipalities, being present in 76 Municipalities where there was canine and human transmission and, according to the same, the Municipality of Guarulhos [2], which was classified as "silent" (without confirmation of human and / or canine cases), not receptive (there is no confirmation of presence of the vector). Therefore, the objective of this work was to report the first case of non-autochthonous CVL in the Municipality of Guarulhos.

\section{MATERIALS AND METHODS}

A male canine, two years (y) old was selected to be sent to a private veterinary clinic in the City of Guarulhos, State of São Paulo, Brazil, which had been treating a dermatopathy for two months (mon) with suspicion of hemoparasitosis on July 16, 2018. The owner reported as main complaints: diarrhea, weight loss, alopecia and intense itching, and that the animal was not improving with the use of Cephalexin (15 miligrams $(\mathrm{mg}) \cdot$ kilogram $^{-1}(\mathrm{~kg})$, twice a day-d-). It was also reported that the dog had infestation by ticks and that this from Votuporanga City, São Paulo State, about 530 kilometers (km) away from the city which was attended (FIG.1).
Clinical examination revealed generalized alopecia, tachycardia, tachypnea, cachexia and onychogrifosis. The mucous membranes were hypocorate, rectal temperature of $39.8{ }^{\circ} \mathrm{C}$, generalized lymphadenomegaly and abdominal palpation pain. Blood samples were then collected for blood counts and biochemical measurements by jugular vein puncture and then sent to the laboratory for clinical analysis. A coproparasitological examination was performed in which the presence of Giardia spp. and skin scraping where the presence of mites was not detected. Due to the history of infestation by ticks (Rhipicephalus sanguineus) and the presence of some clinical and laboratory alterations, a blood sample was collected for diagnostic kits for the detection of Ehrlichia canis, Anaplasma spp., Borrelia burgdorferi (Canine Snap 4Dx Plus Test, IDEXX®) and Canine distemper (Alere Cinomose Ag Test Kit $\left.{ }^{\circledR}\right)$ in which both presented negative results.

\section{RESULTS AND DISCUSION}

Considering the negative results and the animal's history, which came from the Municipality of Votuporanga, the chosen test to perform a rapid test for leishmaniasis (Alere Leishmaniose Ac Test $\left.\mathrm{Kit}{ }^{\circledR}\right)$, which consists of a chromatographic immunoassay (CI) [8], in which the qualitative detection of antibodies was carried out by means of the association of the antigens rK39, rK26 and rK9, where it showed a positive result. As a result, the blood sample was evaluated by the Polymerase Chain Reaction (PCR), test to detect the deoxyribonucleic acid (DNA) of the agent using the Wizard Genomic DNA Purification Kit, Promega ${ }^{\circledR}$ for extraction and purification of DNA, and primers RVI (sense;5'CTTTTCTGGTCCCGCGGGTAG-3') and RV [6] (antisense;5'CCACCTGGCCTATTTTACACCA-3') to amplify the target sequence of the $L$. infantum DNA fragment on August 1, 2018. The PCR result was positive and, after confirming the result, a joint decision was made with the animal's owner, and the euthanasia procedure was approved according to resolution 1,000 of May 11, 2012 [1].

Because it is a disease with a wide variety of clinical signs, the diagnosis can become confused, since it can be confused with
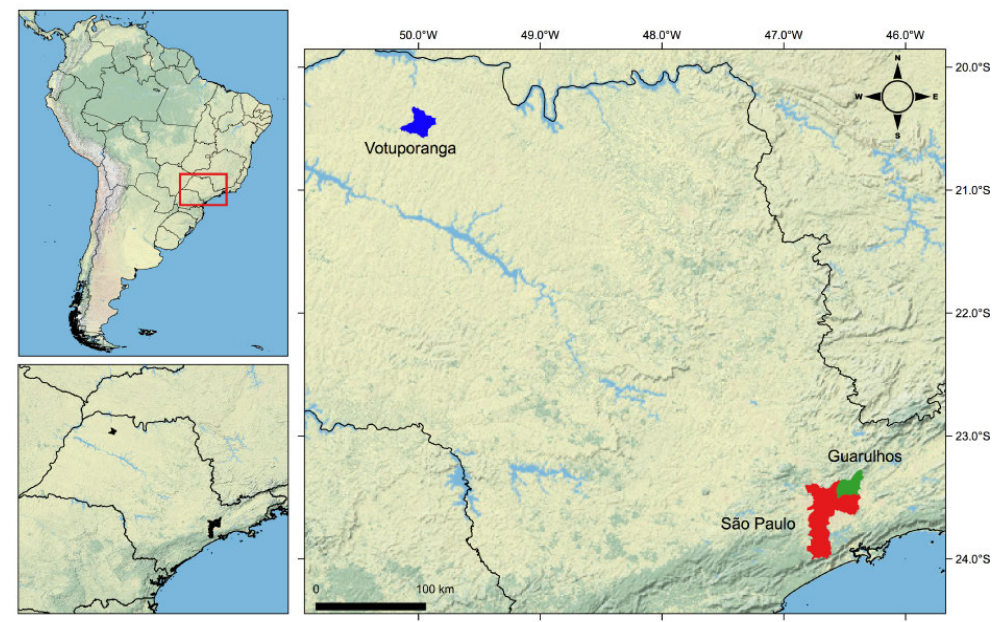

FIGURE 1. Map of the state of São Paulo highlighting the municipalities related to occurrence of the case of leishmaniasis. The following municipalities are cited: Guarulhos, the first case of non-autochthonous LVC; Votuporanga, origin of the animal; and São Paulo 
Revista Cientifica, FCV-LUZ / Vol. XXXI, N4, 137 - 139, 2021

other pathologies [4], which can take advantage of failures in the immune system triggered by the disease.

The biochemical parameters altered in the blood test were: increased bilirubin ( $0.81 \mathrm{mg} \cdot$ deciliter $\left.^{-1}-\mathrm{dL}-\right)$, alkaline phosphatase (286 international units per litre $-\mathrm{L}-$ ), urea $\left(237.1 \mathrm{mg} \cdot \mathrm{dL}^{-1}\right)$ and creatinine $\left(1.72 \mathrm{mg} \cdot \mathrm{dL}^{-1}\right)$, demonstrating a hepatic and renal impairment. As for hematological parameters, normocytic, normocromic and non-regenerative anemia were observed, in addition to thrombocytopenia. These findings were similar to those found by Torrecilha et al. [9] in which they studied the correlation between peripheral parasitic load and clinical and laboratory abnormalities in dogs with CVL, where they found alterations in the hepatic and renal parameters of the dogs studied, and non-regenerative anemia.

There are several techniques for the diagnosis of CVL, such that the association between them provides a greater accuracy, since there is no technique that alone can give a totally accurate diagnosis of the disease [5]. The diagnosis was supported by clinical and pathological findings and validated by serological and molecular techniques [4]. The rapid test for leishmaniasis (Alere Leishmaniose Ac Test Kit ${ }^{\circ}$ ) is a good alternative for screening patients, since it has a good specificity, however its sensitivity is variable, being ideal to combine it with a more sensitive technique like PCR.

As described previously, the animal came from the Municipality of Votuporanga, located in the Northwest Region of the São Paulo State, about $535 \mathrm{~km}$ from Guarulhos (FIG. 1). In this Region there is a wide distribution of the $L$. longipalpis vector, and the Municipality of Votuporanga was classified as an area of transmission of human visceral leishmaniasis (HVL) and CVL [2].

Studies have shown that HVL in the São Paulo State has expanded over the $(y)$ in the Northwest-Southeast direction towards the Bauru Region, as a reflection of the migration of workers from other endemic regions of the Country. This expansion also had as determinant factors the adaptation of the vector to the climatic conditions, the migration of dogs from endemic to non-endemic areas, as well as failures in vector control actions in the domestic reservoirs $[6,7]$. Another factor to consider is the possibility of other vectors acting on the CVL and HVL transmission [3], in which it was pointed out the sandfly Pintomyia fischeri as a potential vector of $L$. infantum in the region of São Paulo, since this one showed susceptibility to parasite development, although it has a lower transmission capacity than $L$. longipalpis.

\section{CONCLUSIONS}

The increasing expansion of Leishmaniose in the São Paulo State, the circulation of people and animals affected from endemic to non-endemic areas, as well as factors favoring the presence of the vector in the urban environment, such as deforestation, presence of garbage and lack of sanitation, and as the possibility of other vectors acting in the transmission of the disease, are conditions for the leishmaniose to continue advancing, being able to settle in non-endemic areas. State surveillance systems are important in the sense of creating a network of information about the quality of information and they are possible to generate a connection between neighboring States to provide a strategic government management to combat anthropozoonotic diseases.

\section{ACKNOWLEDGEMENTS}

Thank Coordination for the Improvement of Higher Education Personnel (CAPES) and Maranhão Foundation for the Support of Scientific and Technological Research and Development (FAPEMA), Brazil.

\section{BIBLIOGRAPHIC REFERENCES}

[1] BEZERRA, JMT; ARAÚJO, VEM; BARBOSA, DS; MARTINSMELO, FR; WERNECK, GL; CARNEIRO, M. Burden of leishmaniasis in Brazil and federated units, 1990-2016: Findings from Global Burden of Disease Study 2016. PLOS Negl. Trop. Dis. 12(9): e0006697. 2018.

[2] CIARAVOLO, RMC; OLIVEIRA, SS; HIRAMOTO, RM; HENRIQUES, LM; TANIGUCHI, HH; JUNIOR, AV; SPINOLA, R; RANGEL, O; TOLEZANO, JE. Epidemiological classification of cities according to the program of surveillance and control of visceral leishmaniasis in the State of São Paulo, Updated in December 2014. BEPA. 12(143): 9-22. 2015.

[3] GALVIS-OVALLOS, F; SILVA, MD; SILVA-BISPO, GB; OLIVEIRA, AG; NETO, JRG; SANTOS-MALAFRONTE, $\mathrm{R}$; GALATI, EAB. Canine visceral leishmaniasis in the metropolitan area of São Paulo: Pintomyiafischeri as potential vector of Leishmania infantum. Parasite 24(2): 1-10. 2017.

[4] MiRó, G; PETERSEN, C; CARdoso, L; BOURdEAU, P; BANETH, G; SOLANO-GALLEGO, L; OLIVA, G. Novel areas for prevention and control of canine leishmaniosis. Trends Parasitol. 33(9): 718-730. 2017.

[5] NAUAR, SJSF. Ocorrência da leishmaniose (Leishmania spp.) no município de Soure - Estado do Pará, no período de janeiro de 2018 a julho de 2019. (Graduação em Medicina Veterinária) - Universidade Federal Rural da Amazônia, Campus Belém, Pará. Trabalho de Conclusão de Curso. 55 pp. 2019.

[6] PESSOA-E-SILVA, R; VAITKEVICIUS-ANTÃO, V; ANDRADE, TAS; OLIVEIRA-SILVA, AC; OLIVEIRA, GA; TRAJANOSILVA, LAM; NAKASONE, EKN; PAIVA-CAVALCANTI, M. The diagnosis of canine visceral leishmaniasis in Brazil: Confront in gold problems. Exp. Parasitol. 199: 9-16. 2019.

[7] ROCHA, MAN; MATOS-ROCHA, TJ; RIBEIRO, CMB; ABREU, SRO. Epidemiological aspects of human and canine visceral leishmaniasis in State of Alagoas, Northeast, Brazil. Braz. J. Biol. 78(4): 609-614. 2018.

[8] SOUZA FILHO, JA; BARBOSA, JR; FIGUEIREDO, FB; JÚNIOR, AAVM; SILVA, SR; COELHO, GLLM; MARCELINO, AP. Performance of Alere ${ }^{\mathrm{TM}}$ immunochromathographic test for the diagnosis of canine visceral leishmaniasis. Vet. Parasitol. 225: 114-116. 2016.

[9] TORRECILHA, RBP; UTUNOMYIA, YT; BOSCO, AM; ALMEIDA, BF; PEREIRA, PP; NARCISO, LG; NUNES, CM. Correlations between peripheral parasite load and common clinical and laboratory alterations in dogs with visceral leishmaniasis. Prev. Vet. Med. 132: 83-87. 2016. 